\title{
Deposition of eosinophil cationic protein in vascular lesions in temporal arteritis
}

\author{
Roger Hällgren, Björn Gudbjörnsson, Erik Larsson, Kjeld Fredens
}

\begin{abstract}
The possible role of the eosinophil and its cytotoxic granule proteins in the vascular lesions seen in temporal arteritis was elucidated. Sixteen sections of biopsy specimens from arteria temporalis showing giant cell arteritis were stained for eosinophil cationic protein (ECP) by polyclonal antibodies and the immunoperoxidase method. Activated eosinophils were identified by monoclonal antibodies linked to alkaline phosphatase. Activated eosinophils and secreted ECP were seen in all layers of the inflamed vessels and were most evident in necrotic lesions and thrombi. Only a small number of granulocytes seen in the adventitia were immunoreactive for cathepsin $\mathbf{G}$, and no extracellular deposits of this neutrophil granule protein were seen. A few immunoreactive eosinophils were found in the adventitia in two of five negative temporal artery biopsy specimens from patients with polymyalgia rheumatica. All eight coronary artery biopsy specimens with atherosclerotic lesions showed no activated eosinophils or secreted ECP. These findings indicate that eosinophils are involved in the vascular lesion in temporal arteritis and suggest that cytotoxic eosinophil granule proteins may contribute to the necrotic lesions and the development of thrombi.
\end{abstract}

Giant cell arteritis in temporal arteritispolymyalgia rheumatica is characterised by patchy necrotic lesions and perivascular infiltrates of, predominantly, histiocytes, lymphocytes, epithelioid cells, and giant cells, which give the lesion its traditional name. The lumen is markedly narrowed by the thickened oedematous intima and at times occluded by thrombi. The possible role of the eosinophil in the vascular lesion in temporal arteritis has not been considered before, as far as we know, partly owing to the limited attention the eosinophil has received in general in inflammatory lesions. Recent findings, however, have suggested that eosinophils may be involved in the vascular injury associated with the hypereosinophilic syndrome ${ }^{1}$ and the eosinophilic granulomatous angiitis of Churg and Strauss. ${ }^{2}$ The cytotoxic properties of the major eosinophil granule proteins, eosinophil cationic protein $(\mathrm{ECP})^{3-6}$ and major basic protein, ${ }^{178}$ suggested that their extracellular deposition may contribute to vascular injury. The activity of ECP on factor XII dependent coagulation pathways ${ }^{9}$ and its neutralising effect on the anticoagulant effect of heparin ${ }^{3}$ may favour the development of thrombi in necrotic vascular lesions. In this study we report that temporal arteritis should be added to the list of vascular diseases characterised by an infiltration of activated eosinophils and extracellular deposits of ECP within the necrotic and thrombotic lesions.

\section{Patients and methods}

Biopsy specimens of the temporal artery showing histological signs of giant cell arteritis were obtained from 16 patients (three male, 13 female; mean age 69 years, range 56-79) before the institution of corticosteroids. Negative temporal artery biopsy specimens from five patients with polymyalgia rheumatica and coronary artery biopsy specimens from eight patients undergoing coronary bypass surgery were obtained for control studies. The biopsy specimens were fixed in a $4 \%$ solution with buffered formaldehyde and embedded in paraffin. Serial sections were studied; the first sections were stained according to routine procedures (haematoxylin/eosin) and the following sections were used for immunohistochemistry. Paraffin sections were dewaxed, rehydrated, and subjected to immunostaining with the antibodies used.

The antibodies used for immunohistochemistry were polyclonal antibodies against $\mathrm{ECP}^{10}$ and a monoclonal antibody, EG2, directed against an epitope on the secreted form of ECP. ${ }^{11}$ This antibody recognises activated eosinophils. ${ }^{11} 12$ To compare eosinophil reactivity with that of the neutrophil an additional antibody against cathepsin G (chymotrypsinlike cationic protein) was included. ${ }^{10}$ The immunoperoxidase method according to Sternberger ${ }^{13}$ was used with polyclonal antibodies against ECP and cathepsin G. The staining procedures with these polyclonal antibodies have previously been described in detail. $^{14}$ The monoclonal antibody EG2 was detected by the unlabelled bridge technique (APAAP procedure). ${ }^{14} \mathrm{~A}$ mouse monoclonal antibody of the same isotope was used as control. Conventional staining controls were used $^{13}$ and specificity controls performed by blocking the reactivity of the antisera with purified ECP. The immune reactivities of cellbound and extracellular ECP were distinguished. ${ }^{14} 15$

\section{Results}

Immunohistochemical staining of the 16 biopsy specimens displaying temporal arteritis showed an infiltration of granulocytes and extracellular 
deposits reactive towards the polyclonal ECP antibody and the monoclonal antibody EG2 (fig 1). Most, if not all, cells and deposits reactive towards the polyclonal ECP antibody were also strongly EG2 positive. In contrast, only a few cells positive for cathepsin $G$ were seen in the adventitia and in eight specimens no cells immunoreactive for cathepsin $G$ were present at all. The number of eosinophils in the cell infiltrates seen by haematoxylin-eosin stain

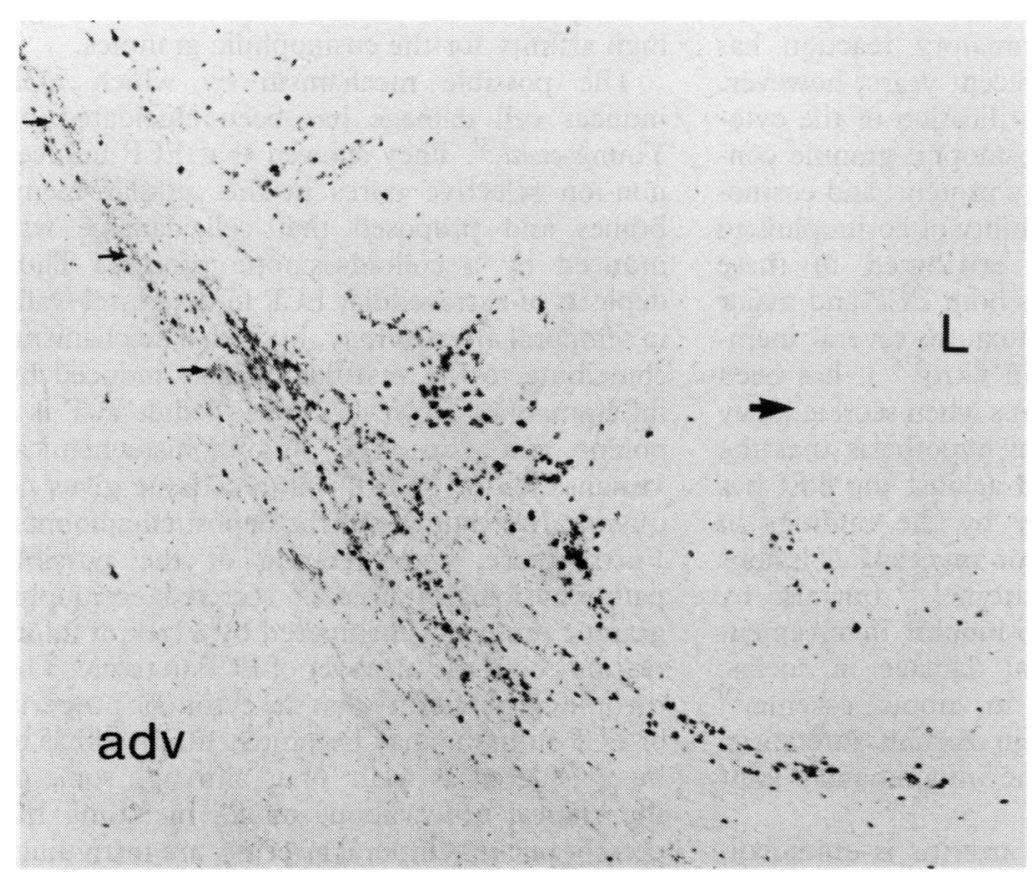

Figure 1 Section of temporal artery with giant cell arteritis. Cells immunoreactive for eosinophil cationic protein $(E C P)$ infiltrate the media. Deposits of extracellular ECP are seen in these areas and are indicated by the small arrows. $L$ indicates the lumen and the large arrow the membrana elastica interna. In the adventitia (adv) only a few cells immunoreactive for ECP are seen (counterstained with toluidine).

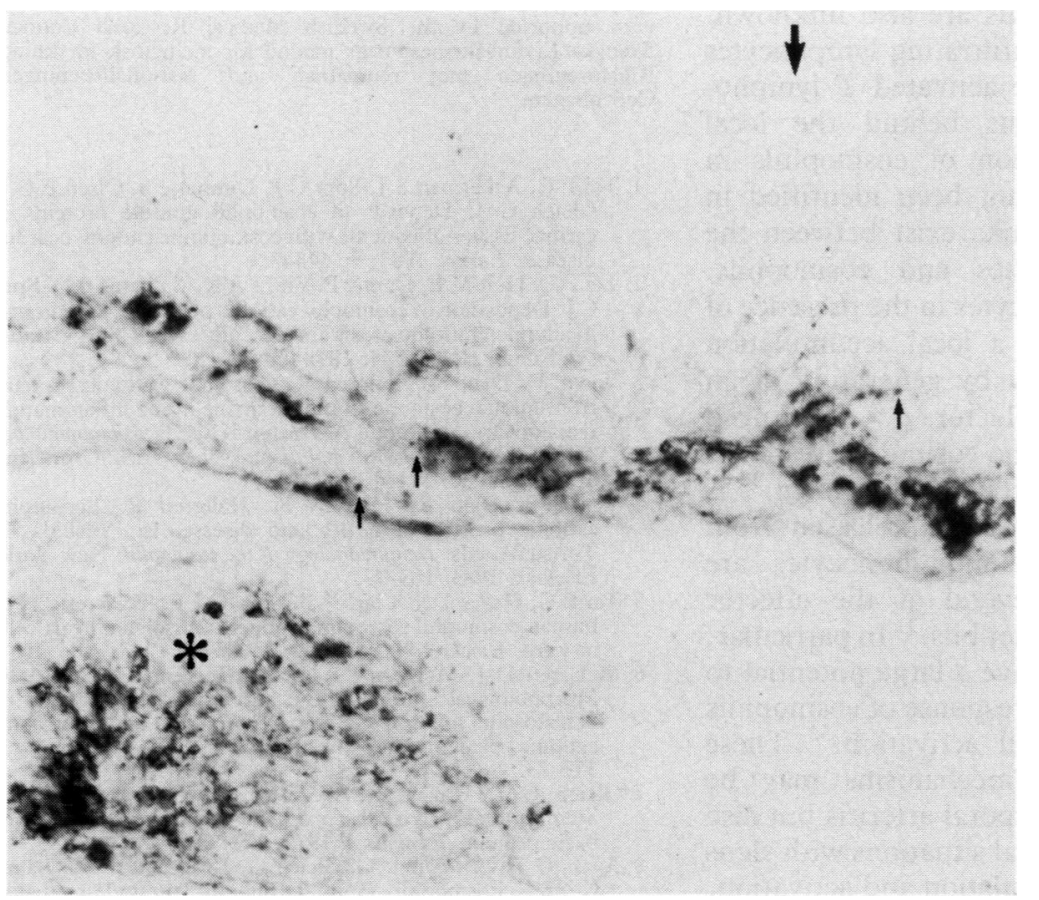

Figure 2 Section of temporal artery from another patient with typical temporal arteritis. Cells immunoreactive for eosinophil cationic protein (ECP) infiltrate the intima, and heavy, granular deposits of ECP are seen (small arrows). Extensive ECP deposits are seen in a thrombus (asterisk). The large arrow indicates the membrana elastica interna. Counterstained with toluidine. was considerably lower than the number identified by immunofluorescence.

Immunoreactivity was rated according to the scale: $0=$ none, $1=\operatorname{dim}, 2=$ moderately bright, $3=$ bright. In all biopsy specimens reactivity for ECP was located to cells infiltrating the adventitia. Six biopsy specimens had a score of 1 , six a score of 2, and four a score of 3. In 12/16 biopsy specimens cells reactive with ECP were seen in the media; nine of these specimens had a score of 1 and three a score of 3 . The immunoreactive cells were localised in areas with round cell infiltration. In 10/16 biopsy specimens cells immunoreactive for ECP were also seen in the intima (fig 2). Eight of these specimens had an immunoreactivity score of 1 and only two had a score of 3 . In all biopsy specimens patchy and mostly dim extracellular deposits of ECP were seen in areas with immunoreactive cells. Striking deposits of ECP were seen in areas with necrotic lesions and in thrombi (fig 2).

The eight coronary arteries with atherosclerotic lesions showed no immunoreactivity for EG2 and no extracellular deposits of ECP. In two of five temporal artery biopsy specimens, which were otherwise negative, a small number of cells immunoreactive for ECP were seen in the adventitia; in one of the specimens the cells were positive for EG2 but had no extracellular deposits of ECP.

\section{Discussion}

This study showed that the vascular damage in temporal arteritis is characterised by an invasion of activated eosinophils and extracellular deposits of the cytotoxic eosinophil granule protein ECP in all layers of the inflamed vessel. Areas with necrotic lesions showed the most extensive deposits of ECP. The discovery of heavy ECP deposits in thrombi in necrotic vascular lesions is of potential interest owing to the effects of ECP on heparin and the coagulation pathways. ${ }^{49}$ In contrast, eosinophils or eosinophil granule deposits were absent from atherosclerotic arteries. Activated eosinophils, however, were identified in the adventitia of otherwise negative temporal artery biopsy specimens from some of the patients with polymyalgia rheumatica.

These findings in temporal arteritis extend the list of vasculitis diseases in which eosinophils play a part. Deposits of eosinophil granule products have previously been reported in the eosinophil granulomas in Churg-Strauss syndrome. ${ }^{1}$ In renal allograft rejections of the vascular type, extensive deposits of secreted ECP can be seen in those arterial walls with necrotic lesions but not in inflamed vessels without necrosis. ${ }^{16}$ Immunohistochemical studies of cardiac tissue of patients with eosinophilic endomyocardial disease have shown that activated eosinophils and secreted eosinophil granule proteins are most evident within the necrotic and, at a later stage, thrombotic lesions of the myocardium, within areas of acute tissue damage in the endocardium and in the walls of small vessels. ${ }^{14}$ Thus eosinophil activation is not specific for certain vasculitic diseases which by tradition have been associated with eosinophil 
involvement but seems to be present in a variety of inflammatory diseases affecting vessel walls.

Most theories of eosinophil function have been related to allergic diseases and parasite infections. A modulatory role for eosinophils in allergic reactions has been proposed, and some support for the hypothesis has been provided. Thus eosinophils may exert a modulating effect on the inflammatory reaction by release of aryl sulphatase $B$, phospholipase $D$, histaminase, and other chemical mediators. ${ }^{17-19}$ The idea of the eosinophil as an innocent bystander or modulator of the inflammatory reaction has been questioned during recent years, however, mainly owing to the identification of the cytotoxic properties of the eosinophil granule constituents ECP, major basic protein, and eosinophil peroxidase. ${ }^{3-8}$ The ability of eosinophils to kill parasites has been attributed to these granular cytotoxins. ${ }^{5-7}$ As both ECP and major basic protein are highly toxic to several mammalian cells and tissues in vitro ${ }^{58}$ it has been proposed that these proteins when secreted may cause tissue damage. The hypothesis that the eosinophil may be turned against the host has been supported not only by the findings in necrotising vasculitides ${ }^{2}$ or myocardial lesions in hypereosinophilic syndrome ${ }^{114}$ but also by observations made on eosinophil involvement in, for example, mucosal damage in coeliac disease, ${ }^{15}$ skin damage in atopic eczema, ${ }^{20}$ impaired lung function in certain interstitial lung diseases, ${ }^{21} 22$ and the inflammatory joint lesion. ${ }^{23}$

The cause of temporal arteritis is unknown. The predilection of temporal arteritis for the white population is striking. This predilection and the appearance of the disease in members of the same family suggested a genetic predisposition. $^{24}$ The pathogenic mechanisms implicated in the vascular accumulation of round cells and giant cells are also unknown. Characterisation of the infiltrating lymphocytes has shown that most are activated $T$ lymphocytes. $^{25}$ The mechanisms behind the local recruitment and activation of eosinophils in temporal arteritis have not been identified in this study but certain links exist between the activation of lymphocytes and eosinophils. Primed clones of lymphocytes in the presence of specific antigens induce a local accumulation of eosinophils, ${ }^{26}$ possibly by generation of an eosinophilic chemotatic factor. ${ }^{27-29}$ The need for a $T$ cell function in the eosinophil response to certain antigens has been clearly shown. ${ }^{30} \mathrm{~A}$ number of endogenous factors released from stimulated lymphocytes and monocytes are reported to augment several of the effector properties of human eosinophils. ${ }^{31}$ In particular, interleukin 5 seems to have a large potential to amplify the proliferative response of eosinophils and to induce eosinophil activation. ${ }^{32}$ These lymphocyte dependent mechanisms may be operative not only in temporal arteritis but also in most of the other clinical situations with signs of local eosinophil accumulation and activation.

Neutrophil granulocytes may also participate in inflammatory tissue injury by their ability to release enzymes and toxic oxygen radicals. ${ }^{33} 34$ The azurophilic granules of the neutrophil contain a number of preformed proteolytic enzymes, including cathepsin $G$, which have the ability to damage the connective tissue matrix. In the vascular lesion in temporal arteritis the absence of neutrophil infiltration was strikingonly a few granulocytes showed immunoreactivity for cathepsin $G$ and no extracellular deposits of this granule protein were seen. Thus conventional staining seems to underestimate the presence of eosinophils in the leucocyte infiltrate owing to the fact that degranulating eosinophils do not stain well with eosin having a high affinity for the eosinophilic granules.

The possible mechanism by which ECP induces cell damage has been elucidated by Young $e t$ al. $^{35}$ They showed that ECP induces non-ion selective pores in the cellular membranes and proposed that cell damage was induced by a colloid-osmotic process. Thus deposits of extracellular ECP in the vessel walls in temporal arteritis may, by such a mechanism, contribute to the vascular damage induced by inflammation. However, even though ECP is a potent cytotoxin, the immunohistochemical visualisation of ECP in injured tissue gives no quantitative estimate of the deposited amounts. Furthermore, interpretation of the possible pathophysiological role of secreted eosinophil granule proteins is hampered by a lack of information about the turnover of ECP in tissue. The theoretical possibility that the cytotoxic property of ECP in tissue may become neutralised has to be considered as well. Thus although some of the clinical observations made, including the present one in temporal arteritis, are intriguing, suggesting that eosinophils play a part in tissue damage, the possibility that eosinophils may have a modulatory role on inflammation cannot be excluded.

We thank Dr P Venge, University Hospital, Uppsala, Sweden for supplying the purified eosinophil cationic protein. This study was supported by the Swedish Medical Research Council Svenska Livförsäkringsbolags nämnd för medicinsk forskning, Riksföreningen mot reumatism and Nationalföreningen, Copenhagen.

1 Tai P-C, Ackerman S J, Spry C J, Dunnette S, Olsen E G J, Gleich G J. Deposits of eosinophil granule proteins in cardiac tissues of patients with eosinophilic endomyocardial disease. Lancet 1987; i: 643-7.

2 Tai P-C, Holt M E, Denny P, Gibbs A R, Williams B D, Spry C J. Deposition of eosinophil cationic protein in granulomas in allergic granulomatosis and vasculitis: the Churg-Strauss syndrome. $B M F$ 1984; 289: 400-2.

3 Venge P, Dahl R, Hällgren R, Olsson I. Cationic proteins from human eosinophils and their role in the inflammatory reaction. In: Mahmoud A, Austen KF, eds. Immunobiolog of the eosinophil in health and disease. New York: Grune and Stratton, 1980: 131-46.

4 Venge P, Dahl R, Fredens $K$, Hällgren $R$. Eosinophi cationic protein in health and disease. In: Yoshida $T$, Torisu M, eds. Immunobiology of the eosinophil. New York: Elsevier, 1983: 163-77.

5 Tai P-C, Hayes D J, Clark J B, Spry C J F. Toxic effects of human eosinophil secretion products on isolated heart cells in vitro. Biochem f 1982; 204: 75-80.

6 McLaren D J, McKean J R, Olsson I, Venge P, Kay A B. Morphological studies of the killing of schistosomula of Schistosoma mansoni by human eosinophil and neutrophil cationic proteins in vitro. Parasite Immunol 1981; 3: cationic

7 Gleich G J, Frigas E, Loegering D A, Wassom D L, Steinmuller D. Cytotoxic properties of the eosinophil majo basic protein. F Immunol 1979; 123: 2925-7.

8 Ayars G H, Altman L C, Gleich G, Loegering D A, Bake $\mathrm{C}$ B. Eosinophil and eosinophil granule-mediated pneumocyte injury. $\mathcal{F}$ Allergy Clin Immunol 1988; 75 595-604.

9 Venge P, Dahl R, Hällgren R. Enhancement of urokinaseinduced plasminogen activation by the cationic proteins of human eosinophil granulocytes. Thromb Res 1979; 14: 641-9. 
10 Olsson I, Venge P, Spitznagel J K, Lehrer R. Arginine-rich cationic proteins of human eosinophil granules. Comparison of the constituents of eosinophilic and neutrophilic leukocytes. Lab Invest 1972; 36: 493-500.

11 Tai P-C, Spry C J F, Peterson C, Venge P, Olsson I Monoclonal antibodies distinguish between storage and secreted forms of eosinophil cationic protein. Nature 1984 309: 182-4.

12 Kierszenbaum F, Villalta F, Tai P-C. Role of inflammatory cells in Chagas disease. III. Kinetics of human eosinophil activation upon interaction with parasites (Trypanazoma cruzi). F Immunol 1986; 136: 662-6.

13 Sternberger L A. Immunohistochemistry. New York: Wiley, 1979.

14 Fredens K, Dybdahl H, Dahl R, Baandrup U. Extracellular deposit of the cationic proteins ECP and EPX in tissue
infiltrations of eosinophils related to tissue damage. APMIS infiltrations of eosin

15 Hällgren R, Colombel J F, Dahl R, et al. Neutrophil and eosinophil involvement of the small bowel in patients with celiac disease and Crohns disease: studies of the secretion rate and immunohistochemical localization of granule constituents. Am F Med 1989; 86: 56-64.

16 Hällgren R, Boman S-O, Fredens K. Activated eosinophil infiltration and deposits of eosinophil cationic protein in renal allograft rejection. Nephron. In press.

17 Hubscher T. Role of the eosinophil in the allergic reactions. II. Release of prostaglandin from human eosinophilic li. Release of prostaglandin from huma

18 Zeiger R S, Twarog F J, Colten H R. Histaminase release from human granulocytes. $\mathcal{F}$ Exp Med 1976; 144: 1049-61.

9 Weller P F, Goetzel E J. The human eosinophil:roles in hos defense and tissue injury. Am $\mathcal{F}$ Pathol 1980; 100: 793-800.

20 Leiferman K M, Ackerman S J, Sampson H A, Haugen H S Venencie P Y, Gleich G J. Dermal deposition of eosinophilgranule major basic protein in atopic dermatitis. Comparison with onchcerciasis. N Engl F Med 1985; 313: 282-5.

21 Hällgren R, Bjermer L, Lundgren $R$, Venge P. The eosinophil component of the alveolitis in idiopathic pulmonary fibrosis. Signs of eosinophil activation in the lung are related to impaired lung function. Am Rev Respir Dis 1989; 139: 373-7.

22 Hällgren R, Samuelsson T, Venge P, Modig J. Eosinophil activation in the lung is related to lung damage in adult activation in the lung is related to lung damage in adult
respiratory distress syndrome. Am Rev Respir Dis 1987; respiratory $639-42$.

23 Hällgren R, Bjelle A, Venge P. Eosinophil cationic protein in inflammatory synovial effusions as evidence of eosinophil involvement. Ann Rheum Dis 1984; 43: 556-62.

24 Liang G C, Simkin P A, Hunder G G, et al. Familial aggregation of polymyalgia rheumatica and giant cell arteritis. Arthritis Rheum 1974; 17: 19-24.

25 Andersson R, Jonsson R, Tarkowski A, Bengtsson B- $\AA$, Malmvall B-E. T cell subsets and expression of immunological activation markers in the arterial walls of patients with giant cell arteritis. Ann Rheum Dis 1987; 46: 915-23.

26 Speirs R S Galianer. Ann Rheum Dis 1987; 46: 915-23. Trentin J J. Lymphoid cell dependence of eosinophil Trentin $\mathrm{J} J$. Lymphoid cell dependence of eosinoph dependence on thymic influence. Exp Hematol 1973; 1: depe-8.

27 Torisu M, Yoshida T, Ward P A, Cohen S. Lymphocytederived eosinophil chemotactic factor. II. Studies on the mechanism of activation of the precursor substance by immune complexes. F Immunol 1973; 111: 1450-8.

28 Colley D G. Eosinophils and immune mechanisms. IV. Culture conditions, antigen requirements, production kinetics and immunologic specificity of the lymphokine eosinophil stimulation promoter. Cell Immunol 1976; 24 328-35.

29 Owhashi M, Nawa Y. Eosinophil chemotactic lymphokine produced by spleen cells of Schistosoma japonicuminfected mice. Int Arch Allergy Appl Immunol 1987; 82: $20-5$.

30 Grove D I, Mahmoud A A, Warren K S. Eosinophils and resistance of Trichinella spiralis. $\mathcal{F}$ Exp Med 1977; 145: 755-9.

31 Spry C J F. Eosinophils: A comprehensive review and guide to the scientific and medical literature. Oxford, New York, Tokyo: Oxford University Press, 1988: 103-11.

32 Lopez A F, Sanderson C J, Gamble J R, Campbell H D Young I G, Vadas M A. Recombinant human interleukin 5 is a selective activator of human eosinophil function. F Exp Med 1988; 167: 219-24.

33 Henson P M. The immunologic release of constituents from neutrophil leukocytes. I. The role of antibody and complement on nonphagocytosable surfaces of phagocytosable particles. F Immunol 1971; 107: 1535-46.

34 Weissman G, Smolen J E, Korchak H M. Release of inflammatory mediators from stimulated neutrophils. $N$ Engl f Med 1980; 303: 27-34

35 Young JD-E, Peterson C G B, Venge $P$, Cohn $Z$ A Mechanism of membrane damage mediated by human Mechanism of membrane damage mediated by hum
eosinophil cationic protein. Nature 1986; 321: 613-8. 